Dept. Surg., Anaesth. \& Radiol.

Fac. Vet. Medicine, Cairo Univ.

Head of Dept. : Prof. Dr. Y Khamis

\title{
CONGENITAL ENCEPHALOCELE IN TWO KIDS
} (With 4 Fig)

\section{By}

\section{S.T. EL-ZOMOR; K.A. FARAG; M.B. MOSTAFA*;} and F.M. FARAG**

(Received at 6/9/1993)

\section{فتاق دماغ وراثٔ فى جديين}

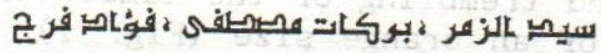

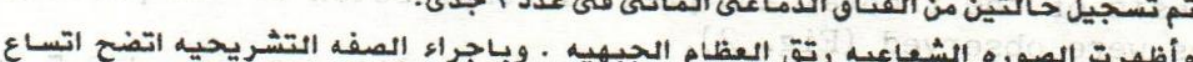

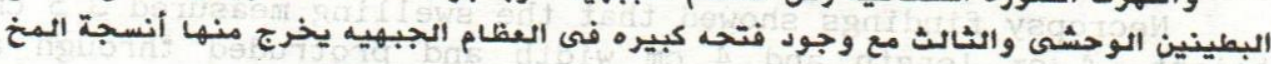

*: Dept. Vet. Surgery, Anesthesiology and Radiology, Cairo Univ.

**: Dept. Vet. Anatomy, Cairo Univ. 


\section{S.T. EL-ZOMOR et al.}

\section{SUMMARY}

Encephalocele associated with hydrocephalus were recorded in two kids. The radiographic appearance showed partial agenesis of the frontal bone. The necropsy finding revealed dilated lateral and third ventricles, large bone cleft in the frontal bone and protrusion of the brain tissues with its meninges through this cleft (Encephalocele).

\section{History and clinical examination:}

Two kids 3 days old were admitted to the Surgery Clinic, Faculty of Veterinary Medicine, Cairo University, with a history of swelling at the frontal region. The clinical examination revealed dullness, proptosis of the left eyes, incoordination and trembling of the limbs. The swellings were fluctuating and of an orange size (Fig. 1). Plain radiograph showed a radioopaque swelling at the frontal region. Partial agenesis of the frontal and partial compression of the parietal bones were observed (Fig. 2).

Necropsy findings showed that the swelling measured $3.5 \mathrm{~cm}$ height, $4 \mathrm{~cm}$ length and $4 \mathrm{~cm}$ width and protruded through a defect in the frontal bone. Longitudinal section of the head revealed that the swelling consisted of dilated lateral ventricles filled with cerebrospinal fluid, surrounded by part of cerebral hemisphere with its meningeal investment (Fig. 3).

The lateralventricles were severely dilated and accompanied by dilation of the interventricular foramen (Foramen of Monro) The frontal pole of the cerebral hemisphere was thin walled measuring, $1.5 \mathrm{~mm}$ cranially and $1 \mathrm{~mm}$ caudally. The occipital pole was abnormally overlaped on the cerebellum and corpora quadrigemina (Fig. 4). The frontal bone defect is ovoid in shape and extended from the frontonasal suture cranially to about $0.5 \mathrm{~cm}$ from the frontoparietal suture caudally.

\section{DISCUSSION}

The clinical, radiographic and necropsy findings revealed partial bone agenesis (Cranium bifidum) with protrusion of brain tissues with its meninges (Encephalocele). Moreover, the lateral ventricles were dilated and filled with CSF (Hydrocephalus). There is no available record of such case in kids, however, similar cases were previously reported in pups (CARMICHEAL et al, 1983) in calves (KHAMIS et al., 1992), in pigglets (STEWART et al., 1972; and Vogt et al.1986), and in

Assiut Vet. Med. J. Vol. 30, No. 59, October 1993. 
infants (NELSON et al., 1975). Most studies incriminated hereditary influence on the development of such cases (STEWART et al., 1972; VOGT et al., 1986; and OJALA et al.., 1992). However, de LAHAUNTA et al. (1983) attributed the cause of similar cases in pups to malformation of the mesencephalic aquiduct resulting in a non communicating obstructive hydrocephalus with severe dilation of the third and lateral ventricles. This may be accompanied by a massive expansion of the cranial cavity and occurrence of large nonossified portions of the calvaria. Moreover, NELSON et al. (1975) mentioned that encephalocele is accompanied with hydrocephalus in approximately two thirds of affected infants. In conclusion, dilation of the lateral and third ventricles with CSF leads to formation of hydrocephalus. The resultant massive expansion of the cranial cavity produced bone cleft in the frontal bone through which herniation of the brain tissues with its meningeal covering would occur forming encephalocele.

\section{REFERENCES}

Carmichael, S.; Griffiths, J.E. and Harvey, J.A. (1983): Familiar cerebral ataxia with hydrocephalus in bull mastiffs. Vet. Rec. 98, 354-358.

De Lahunta, A.; Sadler, L.L. and Hamilton W.P. (1983): Veterinary neuroanatomy and clinical neurology. 2nd Ed. W. B. Saunders Comp.

Khamis, Y.; Hassanen, A. and Abdel Hamid M.A. (1992): Hydroenzephalcele bei einem Agyptischen Kalb einheimischen Rasse. Tierarztl. Umschau 47, 364.

Nelson, W.E.; Vaughan V.C.V.; Mekay, R.J. and Behrman, R.E. (1975): Nelson Textbook of pediatrics. W. B. Saunders Comp. Philadelphia London Toronto.

Stewart, R.W.; Selby, L.A. and Edmonds, L.D. (1972): A Survey of cranium bifidum. An inherited defect in swine. V.M / S A C $67,677-681$.

Vogt, D.W.; Ellersieck, M.R.; Deutsch, W.E.; Akremi, B. and Islam M.N. (1986): Congenital meningocele encephalocele in an experimental swine herd. Am. J. Vet. Res. 47, 188-191.

Ojala, M. and Ala-Huikku, J. (1992): Inheritance of hydrocephalus in horses. Eq. Vet. J. 24, 140-143.

Assiut Vet. Med. J. Vol. 30, No. 59, October 1993. 
S.T. EL-ZOMOR et al.

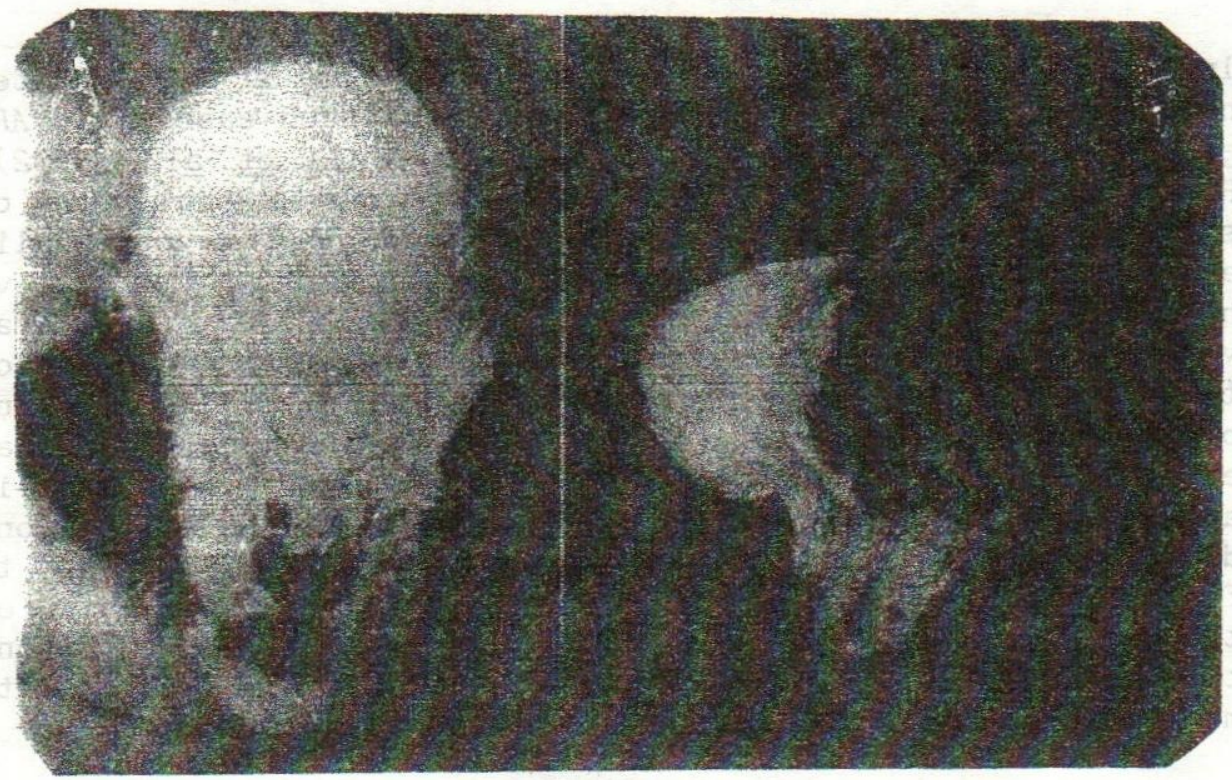

Fig 1: Encephalocele in a kid.

Left: Anterior vien showing proptosis of the left eye.

צ.

Right: Lateral view showing swelling at the frontal region

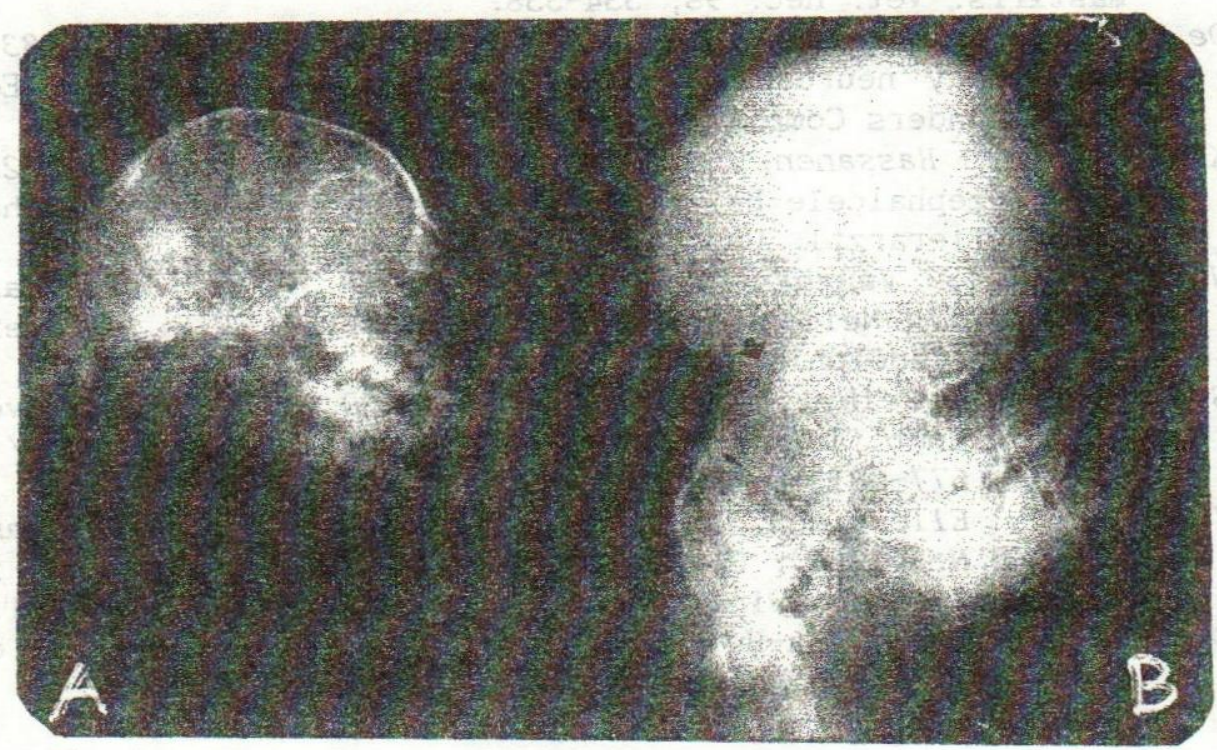

Fis. 2: Laceral piatif radiograph ot tha heal.

A: Normal radiograph.

B: Radiograph of kid affected With encephaiocelot snowing radioopaque swelling. compressed parietei bone

short arrow), and partial agenesis of the ironta: bone (coarse arrow).

Assiut Vet. Med. J. Vol. 30, No. 59, October 1993. 
CONGENITAL. ENCEPHALOCELE \& KIDS

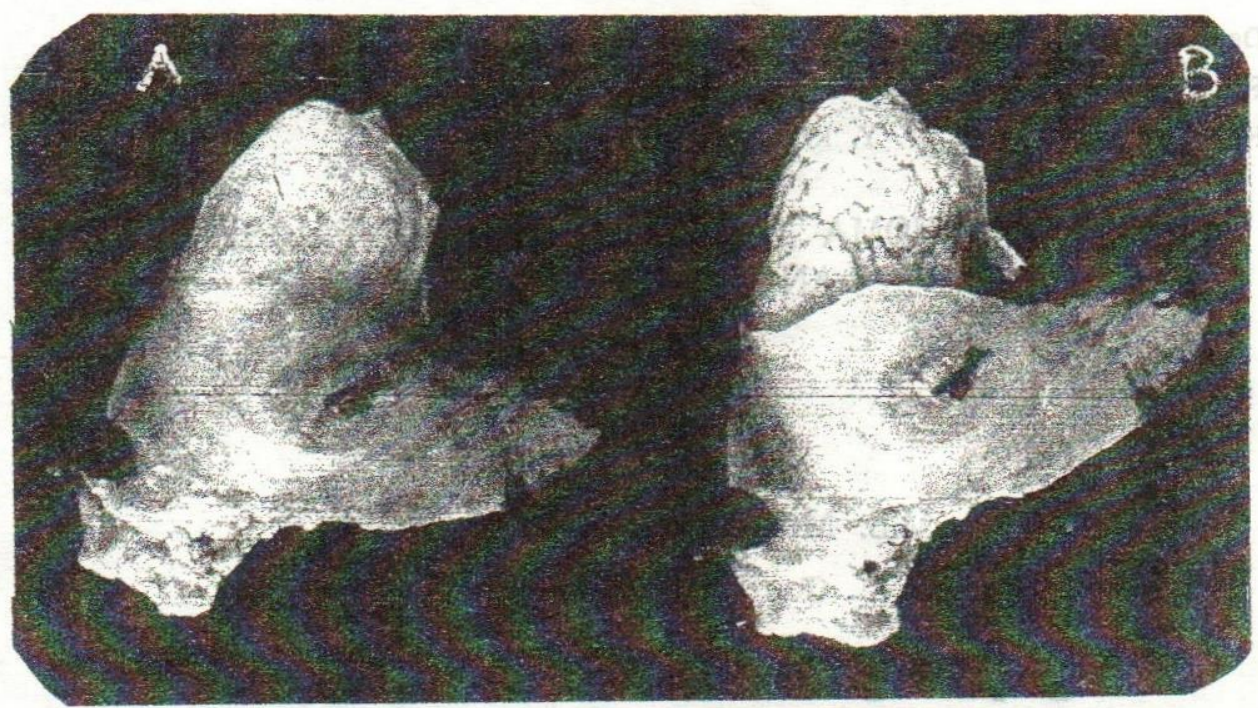

Fig. 3: Lateral view of the right side of the head specimen showing the frontal defect and prolapsed part of the cerebral hemisphere

$A$ : Before removal of the meninges.

B: After removal if the meninges.

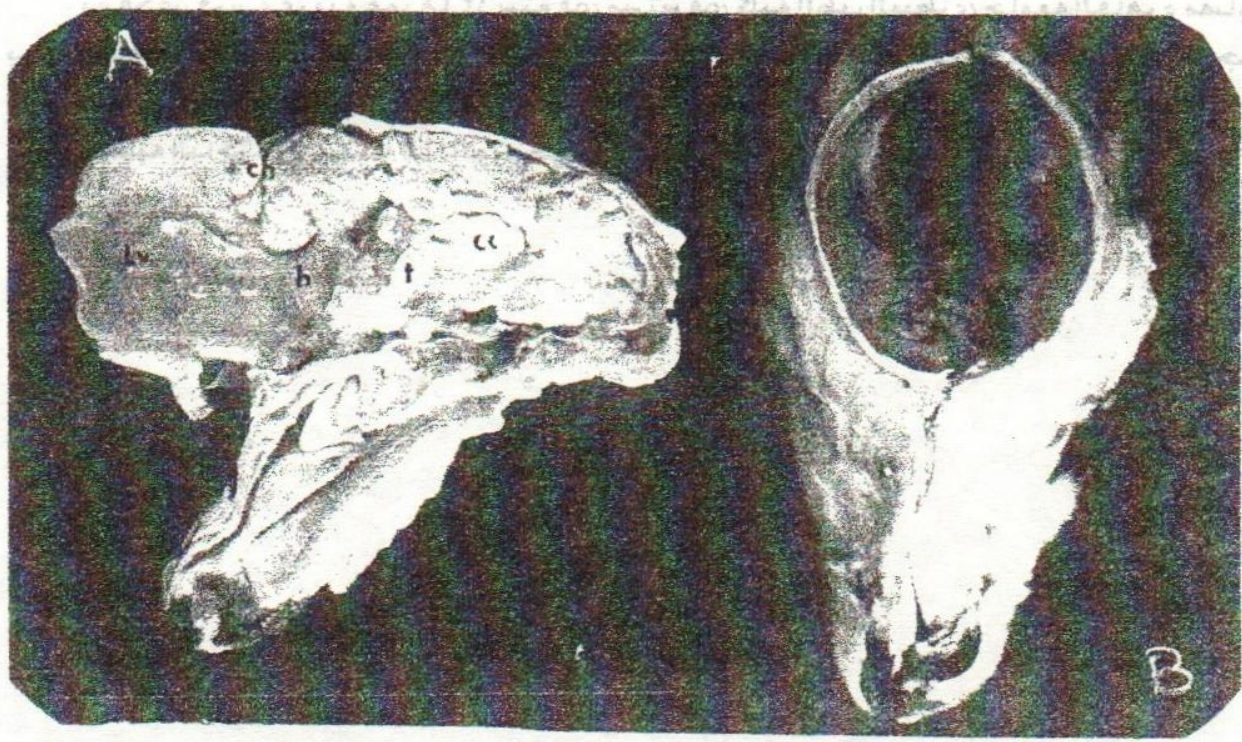

Fig. 4 A: Medial view of the right side of the head specimen

Iv: lateral ventricle ch: cerebral hemisphere

ci: cerebellum

t: thalamus

$c q$ : corpora quadrigemina

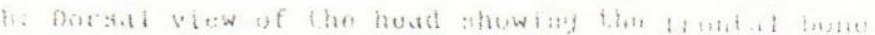
defect.

Assiut Vet. Med. j. Vol. 30, No. 59, October 1993. 